\title{
Raud, «Le texte d'un roman»: Journal intime et fictionnalisation de soi
}

\section{Elisa Bricco}

\section{Q OpenEdition}

1 Journals

\section{Edizione digitale}

URL: https://journals.openedition.org/studifrancesi/41246

DOI: 10.4000/studifrancesi.41246

ISSN: 2421-5856

\section{Editore}

Rosenberg \& Sellier

\section{Edizione cartacea}

Data di pubblicazione: 1 juillet 2004

Paginazione: 223

ISSN: 0039-2944

\section{Notizia bibliografica digitale}

Elisa Bricco, «Raud, «Le texte d"un roman»: Journal intime et fictionnalisation de soi», Studi Francesi [Online], 142 (XLVIII | I) | 2004, online dal 30 novembre 2015, consultato il 09 septembre 2021. URL: http://journals.openedition.org/studifrancesi/41246; DOI: https://doi.org/10.4000/studifrancesi. 41246

Questo documento è stato generato automaticamente il 9 septembre 2021.

\section{(c)}

Studi Francesi è distribuita con Licenza Creative Commons Attribuzione - Non commerciale - Non opere derivate 4.0 Internazionale. 


\title{
Raud, «Le texte d'un roman»: Journal intime et fictionnalisation de soi
}

\author{
Elisa Bricco
}

\section{NOTIZIA}

RAUD, «Le texte d'un roman»: Journal intime et fictionnalisation de soi, «L'Esprit Créateur», 2002, XLII, 4, pp.76-84

1 Il difficile rapporto tra la scrittura diaristica e la realtà è una delle interrogazioni più diffuse nella critica contemporanea. Qual è il confine tra diario e autofiction?

2 Tracciando una sorta di vademecum per coloro che non sono ancora sicuri nella definizione tra queste due forme di scrittura, l'A. pone l'accento sull'aderenza al reale come primaria necessità perché vi sia una scrittura diaristica, ma spesso, però, reale $\mathrm{e}$ fiction s'intersecano nei diari degli scrittori contemporanei e il limite tra le due istanze è difficilmente percepibile. Così, BRAUD viene a puntualizzare che ogni riscrittura è in un certo qual modo filtrata dall'immaginazione e dall'estetica - tanto più che il suo campo d'indagine comprende testi di scrittori: Ch. Juliet, A. Ernaux, R. Camus, M.-E. Nabe, Ch. Bobin, H. Guibert - e dunque, nonostante gli autori dichiarino una forte volontà di adesione al reale senza elaborazione autofictive, l'affabulazione rimane una delle componenti del racconto della vita. 